\title{
JAN PAWEL II, TEORIA EWOLUCJI I INTELIGENTNY PROJEKT
}

Przedmiotem niniejszego artykułu są dwa pojęcia - teoria ewolucji i inteligentny projekt w odniesieniu do nauczania Jana Pawła II. Ponieważ pojęcia te same w sobie stanowią o głębi tematyki i zagadnień, dwie pierwsze części artykułu poświęcimy wyłącznie na ich precyzyjne zdefiniowanie. Sporo uwagi poświęcimy zwłaszcza teorii ewolucji i spróbujemy pokazać, jak kontrastuje ona z klasyczną filozofią i teologią chrześcijańską. Dopiero w części trzeciej przejdziemy do powiązania tych pojęć $\mathrm{z}$ nauczaniem wielkiego świętego. Natomiast w ostatniej - czwartej części przedstawimy syntetyczną analizę współczesnej sytuacji Kościoła w kontekście nauczania na temat teorii ewolucji i inteligentnego projektu.

\section{Teoria ewolucji}

\subsection{Ewolucja biologiczna}

Teoria ewolucji to pojęcie bardzo ogólne, w które można wpisać niemal każdy przejaw współczesnej nauki - zarówno przyrodoznawstwa, jak i nauk historycznych lub społecznych. Możemy mówić na przykład o ewolucji w świecie kultury, o ewolucji języka, ludzkiej świadomości, systemów politycznych, praw, norm moralnych itp. Aby zbliżyć się do istotnego dla nas rozumienia ewolucji, musimy najpierw rozróżnić świat natury - przyrodę lub świat widzialny - oraz świat kultury, czyli przestrzeń racjonalnych wytworów człowieka, takich jak technika, prawa, sztuka czy nauka. Przedmiotem naszego zainteresowania jest ewolucja w świecie natury. Jednak i to rozumienie jest 
jeszcze za szerokie. Można bowiem mówić o ewolucji kosmicznej, chemicznej, biochemicznej i biologicznej. W ramach ewolucji kosmicznej mieszczą się teorie powstawania gwiazd i układów planetarnych, koncepcje powstania i budowy Kosmosu, takie jak teoria Wielkiego Wybuchu. Natomiast ewolucje chemiczna i biochemiczna dotyczą powstawania cząstek organicznych z nieorganicznych, a następnie życia $z$ „,nieżycia”. W centrum naszego zainteresowania znajduje się jednak ewolucja biologiczna, czyli ta, która dotyczy zmian w świecie przyrody ożywionej, konkretnie zmian gatunków istot żywych. Teoria Darwina to mechanizm opisujący ewolucję biologiczną.

\subsection{Zmiana w czasie a ewolucja}

Ustaliliśmy jak dotąd, że przedmiotem naszych zainteresowań jest ewolucja biologiczna, czyli zmiany organizmów żywych na przestrzeni czasu. Czy jednak każda zmiana w świecie biologii jest ewolucją? Dotykamy tutaj ważnego zagadnienia.

Czasami ewolucję definiuje się jako po prostu „zmianę w czasie”. Jest to najbardziej ogólne pojęcie ewolucji, które może odnosić się zarówno do świata natury, jak i kultury. Zauważmy jednak, że taka definicja mieści w sobie niemal wszystko (to znaczy każdą zmianę) i dlatego może łatwo prowadzić do nieporozumień. Jeżeli ewolucję zdefiniujemy po prostu jako zmianę w czasie, to pojęcie to nie budzi żadnych kontrowersji. Nikt rozumny nie zaprzeczy bowiem, że wszystko, zarówno w świecie natury, jak i w świecie kultury, zmienia się na przestrzeni czasu.

A jednak problem nie jest tak banalny, jak mogłoby się wydawać. Odwołajmy się do dwóch przykładów, aby zobrazować, jak definicja ewolucji jako „zmiana w czasie” może prowadzić do nieporozumień.

W kosmologii twierdzi się czasem, że gwiazdy ewoluują. Pod pojęciem tym rozumie się naturalny proces formacji gwiazd $\mathrm{z}$ obłoku międzygwiazdowego, następnie ich w miarę niezmienione trwanie przez kilka miliardów lat, w czasie których ciała te spalają materię, z której są zbudowane. Pod koniec swojego życia gwiazdy pęcznieją i zamieniają się w czerwone giganty, następnie eksplodują, zostawiając po sobie białe karły i mnóstwo pyłu w przestrzeni kosmicznej. Astronomia dostarcza wystarczająco dużo danych, aby wnioskować o takim losie gwiazd. Nazywając jednak ten proces „ewolucją”, nie mamy na myśli powstawania żadnej nowości. Jest to pewien schemat powstawania i ginięcia ciał niebieskich. Podobnie można by powiedzieć, że na oceanie powstają fale, które zbliżając się do brzegu, piętrzą się, załamują się i rozmywają na piaszczystej plaży. Obserwując to proste zjawisko, nie jesteśmy 
jednak skłonni do mówienia o „ewolucji fal” czy „ewolucji oceanu”. Zmiana, którą widzimy, nie prowadzi bowiem do niczego nowego, jest powtarzalna i zachodzi na skutek znanych procesów fizycznych.

W podobny sposób można „nadużyć” słowa „ewolucja” w biologii, kiedy ma się na myśli jedynie następstwo pokoleń wśród organizmów żywych ${ }^{1}$. Kot poczyna kota, który od formy embrionalnej przechodzi do życia płodu, następnie rodzi się, dorasta i dojrzewa, po czym starzeje się i umiera. Podobny cykl biologiczny zachodzi u jego potomstwa. I tutaj nie powstaje nic nowego. Następstwo pokoleń jest procesem oczywistym, obserwowalnym i dobrze poznanym (w przeciwieństwie do samego procesu życiowego, jak i wielu szczegółów życia biologicznego, które nadal stanowią zagadkę zarówno dla biologów, jak i filozofów), ale w następstwie pokoleń istot żywych nie mamy do czynienia z powstaniem czegoś nowego lub radykalnymi zmianami biologicznymi. Naturalne następstwo pokoleń stanowi jedynie manifestację tego, co już jakoś zaistniało wcześniej.

Musimy więc uznać, że słowo „ewolucja” dodaje coś do zwykłego pojęcia „zmiany w czasie”, a jednocześnie zmiana w czasie nie powinna być nazywana ewolucją. Czym jest to coś? Odpowiedź nie jest łatwa, ale musimy jej udzielić, aby zrozumieć, czego dotyczy debata na temat ewolucji, będąca przedmiotem naszego zainteresowania.

Klasyczne rozumienie ewolucji wyraził św. Augustyn w swojej koncepcji logoi spermatikoi (łac. rationes seminales, pol. racje zalążkowe). Augustyńskie rozumienie ewolucji sięga do źródłosłowu: ewolucja (od łac. e-volvere) oznacza roz-wój, roz-winięcie czegoś, co wcześniej istniało w jakiejś „zwiniętej” lub ukrytej postaci - w postaci racji zalążkowych. Zatem w ujęciu Augustyna ewolucja to odsłonięcie lub ujawnienie jakiejś natury, wszak nie jest to jej powstanie czy stworzenie, lecz jedynie ujawnienie.

Jak wiadomo, Augustyn użył stoickiej koncepcji racji zalążkowych do interpretacji opisu stworzenia z Księgi Rodzaju. Biblijny opis stworzenia stanowił dla niego nie lada tajemnicę. $Z$ jednej strony chciał utrzymać do-

\footnotetext{
$1 \quad$ Por. np. orzeczenie Komitetu Biologii Ewolucyjnej i Teoretycznej PAN, w którym czytamy: „,[E]wolucja nie jest procesem celowym, w związku z czym gatunki nie mają żadnych «zadań». Ewolucja na drodze doboru naturalnego polega na zróżnicowanym rozrodzie i przeżywaniu osobników różniących się genetycznie. Ten prosty mechanizm, działając na organizmy żywe wystarczająco długo, może doprowadzić do utrwalania się różnorodnych, najbardziej wyszukanych adaptacji”.

${ }^{h t}$ tp://m.wyborcza.pl/wyborcza/1,105407,13357978,Teoria_ewolucji_nie_daje_argumen tow_do_wyglaszania.html [02.03.15].
} 
skonałość Bożego działania, z drugiej zaś znajdował w biblijnym opisie pewne następstwo doskonałości - Bóg wyłania świat z niczego, a następnie na przestrzeni sześciu dni doskonali go przez swoje nadprzyrodzone działanie. Takie stopniowe kształtowanie i doskonalenie świata nie pasowało do raczej greckiej niż hebrajskiej mentalności Augustyna. Jednak z drugiej strony wierzył w prawdziwość (historyczność) wydarzeń opisanych w Księdze Rodzaju. Dlatego musiał dokonać pewnego kompromisu między filozofią a objawieniem. Uznał więc, że Bóg stworzył wszytko od razu w jednym akcie, ale niektóre natury w postaci ukrytej, tak aby mogły się później ujawniać na przestrzeni czasu. Warto dodać, że Augustyn w zasadzie nie był pewien, czy dobrze interpretuje opis stworzenia ${ }^{2}$. Jego koncepcja zaważyła jednak na całej tradycji chrześcijańskiej i oddziałuje aż po dziś dzień.

Widzimy teraz, że pojęcie ewolucji u Augustyna ani nie zaprzecza osobnemu stworzeniu gatunków, ani nie neguje literalnego sensu Księgi Rodzaju. Augustyn jedynie szukał dość specyficznego literalnego sensu opisu stworzenia, aby dopasować go do wymagań greckiej filozofii. Dla naszego tematu istotne jest to, że ewolucja dla Augustyna nie oznacza powstawania nowych natur, lecz jedynie ich ujawnienie na przestrzeni czasu. Zatem ewolucja w oryginalnym chrześcijańskim sensie nie jest jedynie zmianą w czasie, lecz rzeczywistym ujawnieniem czegoś, co wcześniej nie było widoczne. Ale jednocześnie ewolucja w ujęciu Augustyna nie jest powstaniem czegoś fundamentalnie nowego ${ }^{3}$.

Karol Darwin wiedział, że słowo „ewolucja”, tak jak rozumiano je w chrześcijańskiej tradycji filozoficznej, nie oznacza tego, co on sam ma na myśli. Jego teoria wymaga bowiem nie tylko ujawniania ukrytych natur, lecz ich nieustannego powstawania. I dlatego w pierwszych wydaniach swojego głównego dzieła O powstawaniu gatunków (1859) nie używał słowa „ewolucja”. Wprowadził je dopiero później, po tym jak Herbert Spencer przeformułował klasyczne rozumienie ewolucji i wprowadził ideę „ewolucji stwórczej”, czyli domniemanego procesu, który może prowadzić do powstania wszelkich nowości. Można więc powiedzieć, że w ujęciu Darwina ewolucja to idea twórczego mechanizmu, który wytworzył wszystko, co widzimy w biologii,

2 Na przykład w Wyznaniach Augustyn przytacza pięć różnych interpretacji pierwszego wersetu Księgi Rodzaju, z których wszystkie uznaje za uprawnione. Zob. Wyznania, ks. XII, 20, tłum. Z. Kubiak, Kraków 1999, s. 373.

3 Więcej na temat różnic między teistycznym ewolucjonizmem a koncepcją św. Augustyna zob. M. Chaberek, Czy św. Augustyn był teistycznym ewolucjonistą?, „Studia Philosophiae Christianae" 49 (2013) 1, s. 5-23. 
i potencjalnie może wytworzyć wszystko, co tylko może zaistnieć w biologii. Przyjrzyjmy się teraz bliżej nowożytnej koncepcji ewolucji, aby lepiej zrozumieć, jakie wyzwania stawia ona przed tradycyjnym chrześcijaństwem.

\subsection{Chrześcijaństwo a ewolucja}

Religia chrześcijańska wprowadziła do kultury europejskiej paradygmat kreacjonistyczny, to znaczy przekonanie oparte na Piśmie Świętym, że Bóg nie tylko zapoczątkował świat pierwszym aktem stwórczym, ale również kształtował go bezpośrednio swoją nadprzyrodzoną mocą na przestrzeni jakiegoś czasu, który Księga Rodzaju określa mianem sześciu dni. Istotę chrześcijańskiej protologii stanowiły więc dwa elementy: (1) Świat nie jest odwieczny, lecz ma swój absolutny początek, którym jest stworzenie z niczego (łac. ex nihilo). (2) Świat był kształtowany przez Boga zarówno za pomocą przyczyn wtórnych, jak i bezpośrednio, Boskimi aktami stwórczymi, na przestrzeni czasu, który zakończył się definitywnie wraz ze stworzeniem człowieka. W ramach tej wiary mieściło się również przekonanie, że Bóg stworzył różne gatunki roślin i zwierząt w sposób nadprzyrodzony, czy to w postaci nasion, czy dorosłych pierwszych par różnych osobników.

Te dwa punkty stanowiły radykalną nowość w stosunku do mitologii i wierzeń pogańskich, w których świat był odwieczny (nawet jeżeli podlegał przeróżnym metamorfozom), a Bóg (pierwsza przyczyna) nie działał w sposób bezpośredni. Można więc powiedzieć, że chrześcijaństwo całkowicie przemieniło ludzkie myślenie o początkach świata, zmieniając paradygmat naturalistyczny lub mitologiczny na koncepcję biblijną i kreacjonistyczną. Biblijne rozumienie początków dobrze zadomowiło się w kulturze europejskiej przez kilkanaście stuleci jej rozwoju. Jednak ten harmonijny obraz został poddany próbie najpierw w oświeceniowym deizmie, a następnie w pozytywistycznym mechanicyzmie i naturalizmie.

Jednym z najważniejszych punktów chrześcijańskiego rozumienia początków, który szczególnie przeciwstawiał się naturalizmowi, było nadprzyrodzone pochodzenie gatunków. Już Rene Descartes spekulował na temat możliwości pochodzenia wszystkich organizmów żywych od jednego przodka. Taki obraz - jego zdaniem - znacznie „ułatwiłby nam rozumienie tych organizmów"4. Kartezjuszowi chodziło więc o jasność i pewność poznania.

4 „Ponieważ dla rozumienia natury roślin czy istot ludzkich o wiele lepiej jest rozpatrywać, w jaki sposób stopniowo mogły się one rodzić z nasion, aniżeli w jaki sposób Bóg je w początkach świata stworzył, przeto jeśli potrafilibyśmy wymyślić jakieś zasady 
W oświeceniu wspólne pochodzenie zaproponował Erazm Darwin (dziadek Karola Darwina), który w naturalistycznych poetyckich wizjach roztaczał obraz przyrody samokształtującej się pod wpływem wszechmocnych sił rodzenia. Całe życie miało wyłonić się z jednego włókna, w które Bóg tchną na początku element życia. Zdaniem Erazma taki obraz Bożego działania jest lepszy, ponieważ ukazuje Boga jako Przyczynę przyczyn i Byt bytów (Ens Entium), a nie jedynie sprawcę skutków. Jego zdaniem, więcej mocy trzeba, aby wytworzyć przyczynę, niż wywołać sam skutek ${ }^{5}$.

W tym samym czasie we Francji ze swoimi koncepcjami wystąpił Jean-Baptiste Lamarck. Francuski naturalista tym różnił się od Erazma Darwina, że swoje koncepcje przedstawiał jako realistyczny opis powstania świata przyrody, a nie jedynie filozoficzną możliwość. Jego zdaniem wszystkie gatunki istot żywych rzeczywiście ukształtowały się z jednego lub kilku stworzonych przodków na mocy zwykłych działań przyrody. To Lamarck zasłynął porzuconą później na wiele lat koncepcją, że organizmy nabywają organy stosownie do swoich potrzeb we współdziałaniu $z$ otaczającą je przyrodą. Tak na przykład żyrafa ma długą szyję, ponieważ musiała wyciągać się po liście rosnące na wyższych gałęziach, a przodkowie obecnych ptaków zaczęli latać, ponieważ wykonywali coraz dłuższe skoki w pogoni za pożywieniem.

Choć Lamarck przegrał dysputę naukową we Francji (gdzie idee ewolucyjne przycichły na kilkadziesiąt lat), idee wspólnego pochodzenia i ewolucji zdobywały kolejnych propagatorów. W Wielkiej Brytanii na przykład w pełni ewolucyjną historię świata zaproponował Robert Chambers - szkocki geolog amator. Również on nie stronił od teologicznych implikacji swojej teorii. Twierdził, że idea Boga wprawiającego w ruch ewolucję jest znacznie bardziej nobliwa niż twierdzenie, że Bóg stworzył każdego skorupiaka osobno. Jego zdaniem dotychczasowe rozumienie stworzenia wynikało jedynie z błędnej

bardzo proste i łatwe do pojęcia i odwrotnie, że z nich jakby z nasion jakichś mogły powstać i gwiazdy, i ziemia, i wreszcie wszystko, co poznajemy w tym świecie widzialnym, to chociaż wiemy dobrze, że one nigdy w ten sposób nie powstały, jednak tym sposobem o wiele lepiej przedstawimy ich naturę, aniżeli gdybyśmy opisywali tylko, jakie one są teraz”. R. Descartes, Zasady filozofii, przeł. I. Dąmbska, Warszawa 1960, III, 45, s. 121-122.

„Cóż za wspaniała idea nieskończonej mocy wielkiego Architekta! Przyczyna Przyczyn! Rodzic Rodziców! Ens Entium! Jeżeli bowiem porównamy nieskończoności, wydaje się, że większej nieskończoności mocy wymaga wywołanie przyczyn skutków niż wywołanie samych skutków. Ta idea jest analogiczna do poprawiającej się doskonałości obserwowalnej w każdej części stworzenia”. E. Darwin, Zoonomia or the Laws of Organic Life, $3^{\text {rd }}$ American Edition, Boston 1809, Księga XXXIX, IV, 8. 
interpretacji Pisma Świętego i obecnie wiara w osobne stworzenie powinna zostać zastąpiona ideą ewolucji zapoczątkowanej przez Boga ${ }^{6}$.

Poglądy Erazma Darwina, Lamarcka i Chambersa bardzo dobrze wpisywały się w wymagania naturalistycznej, mechanistycznej i deistycznej filozofii oświecenia. Bóg był bardzo doskonały, był pierwszą przyczyną, bytem najwyższym, najdoskonalszym, ale jednocześnie oddzielonym od świata pośrednictwem przyczyn wtórnych, takich jak jakieś domniemane siły ewolucji tkwiące w samej naturze. Bez wielkiej przesady można powiedzieć, że w ewolucyjnej koncepcji powstania świata to przyroda - owe „przyczyny wtórne” uległy pewnemu przebóstwieniu. Właściwie natura stała się bogiem, ponieważ Bóg prawdziwy został wyręczony $\mathrm{w}$ dziele stwórczym poprzez potężną i tajemniczą „siłę rodzenia"7.

Podsumowując, można powiedzieć, że w przeddzień pojawienia się teorii Karola Darwina grunt filozoficzny i kulturowy był dobrze przygotowany. Jednocześnie warto zauważyć, że myśl europejska zatoczyła pełne koło od pogańskiej starożytności do nowożytnego ewolucjonizmu. W pogańskich koncepcjach filozoficznych Bóg nie działał bezpośrednio w stworzeniu. Dla Arystotelesa był pierwszym poruszycielem jednej z pięćdziesięciu sfer niebieskich, ale nie oddziaływał bezpośrednio na świat materialny otaczający człowieka. W systemach platońskich Bóg (Najwyższe Dobro) emanował z siebie szereg bytów pośrednich, z których dopiero jedna z niższych emanacji odpowiadała za wyłonienie świata. W nowożytnych koncepcjach ewolucyjnych podobnie - Bóg nie miał stworzyć gatunków, lecz jedynie przekazać moc ich stworzenia przyrodzie. Wielkość Boga miała się ujawniać w jego „oddzieleniu” od świata. Tak jakby Bóg, który stwarzałby każdy rodzaj bytów ożywionych osobnym aktem, był w jakiś sposób ułomny, niedoskonały. Jaka wizja Boga stała (stoi) za koncepcjami ewolucjonistycznymi?

Przede wszystkim Bóg jest Bogiem odległym i abstrakcyjnym. Nie ingeruje w świat (czy to w historii stworzenia, czy w historii zbawienia), ponieważ bezpośrednie dotknięcie świata niejako umniejszałoby Jego majestat. Bóg jest hojny, ponieważ wynosi do godności swoich współpracowników inne byty

\footnotetext{
6 R. Chambers, Vestiges of the Natural History of Creation, $4^{\text {th }}$ edition, London 1845, s. $157 \mathrm{n}$.

7 Erazm Darwin tak komentował pogląd Dawida Hume’a: „Hume, w swoich pośmiertnie wydanych pismach, umieszcza moce rodzenia znacznie powyżej naszego wychwalanego rozumu i dodaje, że rozum może wytworzyć jedynie maszynę taką, jak na przykład statek lub zegar, ale siła rodzenia tworzy samego twórcę maszyny”. E. Darwin, Zoonomia..., dz. cyt. Księga XXXIX, IV, 8.
} 
materialne. Ale jednocześnie Bóg ten jest tak wielki, że aż oderwany, oddalony od człowieka. Jest czystym aktem, czystym bytem itd. W konsekwencji w umysłach oświeconych filozofów staje się czystą ideą. Zatem nie istnieje już realnie, jest jedynie abstrakcyjnym konstruktem potrzebnym jedynie jako zwornik intelektualnych koncepcji. Staje się jedynie wygodnym sposobem zakończenia niewygodnego ciągu pytań o przyczynę przyczyny.

Warto zauważyć, że pierwsi nowożytni ewolucjoniści - włączając również Karola Darwina - nie byli ateistami. Oni wszyscy głosili ewolucję zapoczątkowaną lub kierowaną przez Boga. Co więcej, twierdzili, że ewolucyjny obraz świata w istocie ujawnia lepszy obraz Stwórcy - jego potęgę i mądrość. A jednak ich Bóg nie był (i nie jest) Bogiem chrześcijan.

Jakby na złość wydumanym koncepcjom teistycznego ewolucjonizmu Bóg chrześcijan na każdym kroku ujawnia się jako ten, który jest blisko i działa bezpośrednio. Który dotyka swoich stworzeń, jest obecny między ludźmi przez cuda i łaskę, a największy dowód jego uniżenia stanowi przyjęcie natury ludzkiej i stanie się człowiekiem ${ }^{8}$. Poprzez wcielenie Bóg stał się Emmanuelem - Bogiem z nami, Bogiem niejako połączonym na zawsze ze światem. W tradycyjnym ujęciu chrześcijańskim owa „bliskość” Boga ma miejsce nie tylko w historii zbawienia, kiedy to Bóg rozmawia z Abrahamem i Mojżeszem, a następnie działa w Kościele poprzez sakramenty i charyzmaty. Owa bliskość miała miejsce również w historii stworzenia. Mówi nam o tym wyraźnie pierwszy rozdział Księgi Rodzaju. Zatem Bóg chrześcijaństwa, choć wielki i wszechmogący, potrafi się uniżyć nawet do bezpośredniego stworzenia bakterii czy ślimaka. Co więcej, właśnie bezpośrednie stworzenie jest wyrazem Jego unikalnej mocy. Żadne stworzenie nie ma bowiem mocy stwarzania. Bóg chrześcijaństwa nie jest jedynie zwornikiem abstrakcyjnych idei teistycznego ewolucjonizmu, lecz Bogiem, który działał realnie i bezpośrednio zarówno w czasie stwarzania świata, jak i w czasie zbawiania, w siódmym dniu, w którym żyjemy obecnie.

\subsection{Teoria Darwina}

Zanim Karol Darwin opublikował swoją książkę O powstawaniu gatunków, idea wspólnego pochodzenia wszystkich form od jednego przodka była już obecna w nauce i filozofii. Jednak wszystkie dotychczasowe teorie mia-

8 „On, istniejąc w postaci Bożej, nie skorzystał ze sposobności, aby na równi być z Bogiem, lecz ogołocił samego siebie, przyjąwszy postać sługi, stawszy się podobnym do ludzi. A w zewnętrznym przejawie, uznany za człowieka, uniżył samego siebie” (Flp 2, 6-8a). 
ły jeden poważny defekt - brakowało im materialnego mechanizmu, który wyjaśniałby, w jaki sposób miałyby powstawać nowe gatunki. Skoro bowiem Bóg nie stworzył gatunków swoim nadprzyrodzonym działaniem, to musiały one powstać na mocy praw przyrodniczych. Darwin uważał, że odkrył takie prawo - była to przypadkowa zmienność i naturalna selekcja.

Najpierw Darwin zaobserwował, że organizmy wydają więcej potomstwa, niż jest w stanie przeżyć. Ideę tę podsunął mu Thomas Malthus w swoim Eseju o zasadach zaludnienia (1798). Zdaniem Malthusa liczba ludności wzrasta wykładniczo, natomiast ilość zasobów (takich jak pożywienie) liniowo, co nieuchronnie prowadzi do głodu i walki o pożywienie w społeczeństwach ludzkich. Darwin uznał, że podobny problem zachodzi w całej przyrodzie ożywionej i dlatego nadmiar potomstwa prowadzi do walki o byt, którą przetrwają osobniki „najlepiej przystosowane” (ang. survival of the fittest). Naturalna selekcja polega właśnie na wyniszczeniu owych słabiej przystosowanych i faworyzowaniu lepiej przystosowanych lub takich, które zdobyły pewną przewagę konkurencyjną. Darwin zakładał również, że cechy, które mają owe „lepiej przystosowane" osobniki, zostaną przekazane na kolejne pokolenia, dzięki czemu w dłuższym czasie owe „korzystne” cechy zdominują całe populacje. Ponadto brytyjski badacz domniemywał, że jeżeli proces naturalnej selekcji będzie trwał dostatecznie długo, to wytworzy całą różnorodność stworzeń od bakterii przez rośliny i zwierzęta aż po człowieka. Zatem nie chodziło mu wyłącznie o drobne zmiany w obrębie tak zwanych gatunków naturalnych (na poziomie taksonomicznym rodzaju lub rodziny, czyli mikroewolucję), lecz o przejścia międzygatunkowe, to znaczy makroewolucję biologiczną.

Teoria Darwina nie była tak doskonała, jak mogłoby się wydawać. Rzeczywiście była to teoria spójna i urzekająca swoją prostotą. Ale nie zawsze to, co jest spójne i proste, jest prawdziwe. Darwin nie potrafil podać, skąd miałyby się brać korzystne zmiany konieczne do działania naturalnej selekcji. Nie wiedział nic o mechanizmach dziedziczenia ani o stałości kodów genetycznych. Nie potrafił także podać żadnego przykładu przejścia makroewolucyjnego, czyli przekraczającego poziom gatunku naturalnego. Wiedział również, że zapis kopalny nie popiera jego teorii, gdyż nie znajdujemy w nim łańcuchów form przejściowych od jednego gatunku do drugiego. O ile jego teoria w pewnej mierze opisywała mikroewolucję, to makroewolucja, którą postulował Darwin, była czystą spekulacją. Zmiany, które obserwował brytyjski badacz, były zmianami w obrębie gatunków. Ale ewolucja jako zmiana w czasie (czyli to, co opisywał Darwin), to nie to samo, co ewolucja rozumiana jako pochodzenie wszystkich form od jednego przodka (to, co Darwin postulował). 
Mimo tych trudności teoria Darwina z pewnymi modyfikacjami wprowadzonymi po odkryciu genów i zasad dziedziczenia (tak zwany neodarwinizm) ${ }^{9}$ stała się jedynym powszechnie obowiązującym wyjaśnieniem różnorodności biologicznej. Stan ten trwa do dzisiaj. I choć wielu badaczy zdaje sobie sprawę $z$ braków teorii (neo)darwinistycznej, to jednak nie są oni skłonni jej porzucić. Często mówi się, że nie mamy lepszego wyjaśnienia pochodzenia gatunków i dlatego nie można porzucić teorii Darwina. Jeszcze częściej rozróżnia się ewolucję jako „fakt” i mechanizm ewolucji. To, co ewolucjoniści nazywają „faktem ewolucji”, to ogólna idea wspólnego pochodzenia i transformizmu jednych gatunków w inne. Natomiast mechanizm to sposób, w jaki jedne gatunki mają zmieniać się w inne. Ponieważ teoria Darwina dotyczy mechanizmu - sposobu powstawania gatunków, to ich zdaniem nawet unieważnienie teorii Darwina nie unieważnia samego „faktu” makroewolucji biologicznej. W efekcie teoria ewolucji jest zarówno nietestowalna, jak i niemożliwa do obalenia metodą naukową. Nosi więc cechy koncepcji raczej filozoficznej lub religijnej niż naukowej. W tym sensie można powiedzieć, że jest bardziej wiarą niż wiedzą (w sensie wiedzy naukowej). Wiarą we wspólne pochodzenie i naturalny transformizm, która szuka mechanizmu mogącego tę wiarę uzasadnić. Ale nawet jeżeli mechanizm się nie sprawdza, wiara pozostaje nienaruszona. Wiara ta zapoczątkowana została w oświeceniowym deizmie, a następnie została uzasadniona darwinizmem. Gdyby nawet darwinizm kiedyś upadł, to wiara i tak nadal będzie trwała. Na tym polega zmiana paradygmatu, która dokonała się w kulturze zachodniej na przestrzeni minionych dwóch stuleci wiara w stworzenie została wyparta przez wiarę w ewolucję. Ogólna teoria ewolucyjna stała się mitem fundacyjnym cywilizacji postchrześcijańskiej.

\subsection{Ewolucja jako redukcjonizm}

Jak już zauważyliśmy, ewolucja bez mechanizmu wyjaśniającego, jak jedne formy życia miałyby się przekształcać w inne, staje się czystą wiarą - przekonaniem filozoficznym lub religijnym na temat początków przyrody. Jako koncepcja naukowa ewolucja nie może istnieć bez mechanicyzmu, czyli materialistycznego wyjaśnienia procesu powstawania zupełnie nowych form życia. Niestety nieuchronną konsekwencją uznania, że taki mechanizm może istnieć, jest przyjęcie naturalistycznego i mechanicystycznego wyjaśnienia fenomenu życia. Ewolucjonizm z konieczności - o ile ma być naukowy - musi

9 Więcej na temat różnic miedzy darwinizmem i neodarwinizmem zob. M. Chaberek, Kościót a ewolucja, Warszawa 2012, s. 32-39. 
być redukcjonistyczny, czyli musi sprowadzać zjawiska wyższego rzędu do zjawisk niższego rzędu.

Historycznie rzecz ujmując, ewolucjonizm darwinowski dobrze wpisał się w całą gamę dziewiętnastowiecznych „izmów”. Ich cechą wspólną było to, że próbowały wyjaśniać rzeczywistość transcendentną w kategoriach immanentnych. Tak na przykład, pozytywizm uważał, że nauki przyrodnicze stanowią ostatni i najwyższy poziom rozwoju ludzkiej świadomości. Filozofia miała odtąd pełnić jedynie funkcję porządkującą wiedzę nauk przyrodniczych, natomiast religia miała być zepchnięta w sferę czystej mitologii porównywalnej z baśniami dla dzieci. Naturalizm uznawał, że wszystkie zjawiska można zredukować do zjawisk przyrodniczych, a te z kolei da się wyjaśnić w ramach wyłącznie świata materialnego. W mechnicyzmie przyjmowano, że każde zjawisko musi mieć naturalne wyjaśnienie, tzn. oparte wyłącznie na immanentnych prawach przyrody. W marksizmie religię uznawano za opium dla ludu, czyli sposób radzenia sobie mas społecznych z wykorzystywaniem przez wąską grupę kapitalistów. Była więc ludzkim wymysłem i złudzeniem. Dla egzystencjalistów, takich jak Nietzsche, religia była efektem resentymentu ludzi słabych wobec silnych; dla freudyzmu przejawem kompleksu psychologicznego. W darwinizmie z kolei nadprzyrodzone działanie Boga, które zgodnie z przekazem biblijnym miało miejsce u początku świata, zostaje zastąpione działaniem przyrody. Przyroda sama tworzy całą różnorodność stworzeń i nie wymaga żadnej nadprzyrodzonej pomocy.

Jednym ze skutków przyjęcia mechanicystycznego powstawania gatunków jest usunięcie celowości lub przyczyny celowej z przestrzeni badań biologicznych. Według Darwina przyroda jest ślepa i sama wytwarza wszystkie gatunki i organy, które jego zdaniem nie powstają ze względu na funkcję, tylko z powodu przypadkowej zmienności kumulowanej przez naturalną selekcję. Ponadto, jeżeli gatunki mogą powstawać na drodze zmian przypadłościowych (drobnych modyfikacji organicznych), to znaczy, że w istocie nie ma gatunków, są tylko ogniwa pośrednie. Nie ma więc czegoś takiego jak natura rzeczy (określonego bytu), są tylko konglomeraty cech. Zatem darwinizm usuwa również przyczynę formalną. W końcu przyczyna sprawcza to nic innego jak ewoluująca materia. W ten sposób przyczyna sprawcza zostaje zredukowana do przyczyny materialnej. Cztery klasyczne przyczyny zostają sprowadzone do jednej, i to najniższej.

Warto dodać, że chrześcijańscy ewolucjoniści (teistyczni ewolucjoniści) zdają sobie sprawę z wymienionych wyżej problemów darwinizmu. Ponieważ jednak w swoich badaniach filozoficznych przyjmują naturalistyczne założe- 
nia, nie odrzucają ani makroewolucji, ani nawet mechanizmu darwinistycznego. Zamiast tego usiłują jakby zewnętrznie ratować teorię Darwina poprzez dodanie jakichś ogólnych twierdzeń na temat tego, jak to przypadkowy proces ewolucji podlega Bożej opatrzności lub jak Bóg kieruje ewolucją ku jej wypełnieniu, lub nawet jak to ewolucja jest „przyczyną wtórną stworzenia”. Jednak im więcej celowości miałoby być w ewolucji, tym mniej mogłoby być w niej darwinizmu. Istotę teorii Darwina stanowi bowiem (jak już powiedzieliśmy) mechanizm współpracy przypadku i konieczności. A taki mechanizm z definicji jest ślepy i materialistyczny. W efekcie teistyczny ewolucjonizm, w ramach którego próbuje pojednać się przypadkowość ewolucji i celowość Bożego stworzenia, grzęźnie w sprzecznościach i aporiach.

\subsection{Ewolucja a stworzenie}

W teistycznym ewolucjonizmie uznaje się, że Bóg posłużył się ewolucją, stwarzając świat. Można wyróżnić trzy rodzaje teistycznego ewolucjonizmu (TE):

Deistyczny, według którego Bóg ustanowił początkowe warunki, takie jak odpowiednie właściwości fizyczne materii, grawitację i siły wiązań atomowych, które umożliwiły tak zwaną samoorganizację materii, czyli ewolucję od nieżycia do życia, a następnie od najprostszych form życia aż po człowieka. Niektórzy teistyczni ewolucjoniści uważają, że Bóg stworzył człowieka poprzez oświecenie ostatniego hominida światłem intelektu lub zdolnością poznania i kochania Boga. Inni dopuszczają jednak możliwość, że ludzka świadomości jest efektem ewolucji mózgu ${ }^{10}$.

Teistyczny ewolucjonizm w formie panteistycznej zakłada, że Bóg jest niejako obecny w stworzeniu i działa w nim „od wewnątrz" w sposób niewidoczny. Z punktu widzenia nauki ewolucja jest więc procesem przypadkowym, natomiast religia dodaje do darwinizmu jakąś głębszą prawdę na temat rzeczywistości, prawdę która znajduje się wyłącznie w sferze wiary. Nie ma żadnych śladów w historii naturalnej, które wskazywałyby na nieciągłość materialnych procesów wywołaną jakimś zewnętrznym działaniem Stwórcy. Niektórzy zwolennicy tego ujęcia twierdzą nawet, że Bóg jest tak głęboko ukryty w świecie i zjednoczony ze światem, że niejako ewoluuje razem z nim lub raczej - że przyroda współewoluuje z Bogiem ${ }^{11}$.

10 Taką możliwość dopuszczał na przykład J. Życiński. Zob. J. Życiński, Bóg i ewolucja, „Tygodnik Powszechny”, 5 stycznia 1997.

11 Reprezentantami tego nurtu teistycznego ewolucjonizmu byliby na przykład J. Życiński, A. N. Whitehead, A. Peacocke. 
Trzeci rodzaj TE można określić jako emanacjonistyczny. W tym podejściu Bóg jest daleko od świata, natomiast wyłania $\mathrm{z}$ siebie pewne pośrednie (mega)struktury odpowiadające za kształtowanie rzeczywistości materialnej. Owe struktury zarządzają ewolucją świata fizycznego ${ }^{12}$.

Czasami teistyczny ewolucjonizm określa się mianem „kreacjonizmu ewolucyjnego"13. Takie połączenie to oksymoron lub wprost logiczna sprzeczność, ponieważ jeżeli coś powstaje na drodze ewolucji, to nie powstaje na drodze stworzenia. Ewolucja jest bowiem materialnym i naturalnym procesem, natomiast stworzenie to nadprzyrodzony i bezpośredni akt Boży. Jedna i ta sama rzecz nie może powstać zarówno na mocy stworzenia, jak i na mocy ewolucji (podobnie problematyczne jest określenie „kreacjonizm naukowy”, ponieważ nauka zajmuje się tym, co naturalne, natomiast Boże akty stwórcze, o których mówi kreacjonizm, to działania ponadnaturalne).

Podsumowując, można powiedzieć, że chrześcijańska nauka o stworzeniu różni się od teistycznego ewolucjonizmu w trzech zasadniczych punktach:

1. Według chrześcijaństwa stwarzać może tylko Bóg. Żadne stworzenie nie może stanowić aktywnej pomocy w tym unikalnym dziele Bożym. Natomiast $\mathrm{w}$ teistycznym ewolucjonizmie różne elementy świata (ewolucja, procesy materialne, przypadkowe mutacje etc.) niejako współtworzą świat razem z Bogiem. W najogólniejszym sensie Bóg posługuje się ewolucją jako przyczyną wtórną stworzenia.

2. W chrześcijaństwie dzieło formowania świata (opus distinctionis i opus ornatus) wymaga bezpośredniej i nadprzyrodzonej aktywności Stwórcy. Natomiast w teistycznym ewolucjonizmie wyklucza się faktyczną nadprzyrodzoną aktywność Boga w dziele formowania gatunków.

3. Według chrześcijaństwa stworzenie świata zakończyło się raz na zawsze wraz z powstaniem człowieka, natomiast według teistycznego ewolucjonizmu ewolucja trwa przez cały czas istnienia świata materialnego i nieustannie prowadzi (lub może prowadzić) do powstania dowolnych nowości biologicznych.

12 Na przykład w ujęciu Michała Hellera Bóg emanuje z siebie lub po prostu utożsamia się z matematyczną strukturą wszechświata (matrycą), która rządzi zjawiskami fizycznymi. Zob. np. M. Heller, Filozofia przypadku, Kraków 2011, s. 185n.

13 Pojęcie to zostało użyte po raz pierwszy przez fundację BioLogos, której zadaniem jest promocja teistycznego ewolucjonizmu w kościołach chrześcijańskich różnych wyznań. Dobrą krytykę pojęcia kreacjonizmu ewolucyjnego przeprowadził M. Pajewski w artykule Wprowadzenie do problematyki sporu ewolucjonizm-kreacjonizm, „Duch Czasów” (2005) 4, s. 15-16, http://www.eioba.pl/a/ma/kreacjonizm-fundamenty [02.03.15]. 


\section{Inteligentny projekt}

\subsection{Powstanie teorii}

Teoria Darwina rozpowszechniła się w środowiskach naukowych dopiero pod koniec XIX wieku. Jednak teoria ta nigdy nie zyskała takiego stopnia poparcia jaki z reguły uzyskują teorie prezentowane w naukach przyrodniczych. Od samego początku istnieli naukowcy, którzy dowodzili braków teorii Darwina na poziomie eksperymentalnym. Jednak ich rzetelna i naukowa krytyka pozostała w cieniu znacznie głośniejszej krytyki z pozycji kreacjonizmu młodej Ziemi. Stanowisko to ukształtowało się w protestantyzmie jako owoc oparcia całości wiary wyłącznie na Piśmie Świętym (łac. sola scriptura). W kontekście zasady sola scriptura trudno było odróżnić, co w Piśmie Świętym jest prawdą „przypadłościową,, a co jest istotne z punktu widzenia wiary. Dlatego fundamentaliści biblijni do wiary w stworzenie dołączyli przekonanie o literalnym rozumieniu skali czasowej historii stworzenia i historii zbawienia. Prawda istotna (z punktu widzenia wiary) została nierozdzielnie powiązana z przekonaniem, że Bóg stworzył świat w ciągu sześciu naturalnych dni (ziemskich dób), a cała historia świata nie trwała dłużej niż 10 tysięcy lat. Taki światopogląd został przeciwstawiony darwinizmowi i zdefiniował całą dyskusję na temat stworzenia i ewolucji na kolejne sto lat (druga połowa XIX wieku - druga połowa XX wieku).

Niestety, spór ewolucjonizmu i kreacjonizmu młodej Ziemi miał kilka wad. Przede wszystkim teorii naukowej przeciwstawiano prawdę religijną. Biblia była nieraz używana niemal jako podręcznik do historii naturalnej. W późniejszej fazie sporu (od lat 60. XX wieku) kreacjoniści młodoziemscy zaczęli wykorzystywać dane naukowe na poparcie swojej interpretacji Genesis. Często prowadziło to do jawnych nadużyć wobec nauki, które wyrażały się w postaci dowolnego i wybiórczego traktowania danych lub podważania potwierdzonych różnymi metodami wyników datowania Ziemi i kosmosu. Kreacjoniści uważali, że dane paleontologiczne stanowią „dowód stworzenia”, z kolei dane archeologiczne miały dowodzić prawdziwości wydarzeń biblijnych. Szukano więc szczątków arki Noego i wykazywano, że globalny potop pokrył wodą nawet szczyty najwyższych gór. Ogólnie zwolennicy kreacjonizmu młodej Ziemi popełniali dwa błędy natury metodologicznej: (1) z tekstu biblijnego próbowali wydedukować prawdy dotyczące świata przyrody i historii naturalnej oraz (2) przypisywali taką samą wartość zasadniczym prawdom biblijnym (takim jak stworzenie, pierwotna szczęśliwość pierwszej pary, grzech pierworodny i wcielenie), jak i szczegółom historycznym czy cza- 
sowym ramom historii biblijnej (wiek świata ok. 6 tysięcy lat, globalny potop w sensie pokrycia wszystkich lądów wodą, obliczenia dotyczące wielkości arki Noego i możliwości zmieszczenia wszystkich zwierząt, brak jakichkolwiek luk w genealogiach etc.).

Tego typu działania kreacjonistów wcale nie pomagały niewierzącym naukowcom zbliżyć się do chrześcijańskiego światopoglądu. Wręcz przeciwnie, w powszechnej świadomości środowiska naukowego utrwalone zostało przekonanie o nieuchronnym konflikcie nauki i wiary. Wiara biblijna zaczęła być postrzegana wręcz jako zagrożenie dla rzetelnych badań naukowych. Przekonanie to zresztą nadal jest bardzo popularne wśród niewierzących naukowców. Na kilka dziesięcioleci dyskusja wokół darwinizmu utknęła w martwym punkcie. Dopiero sformułowanie teorii inteligentnego projektu umożliwiło wyjście z impasu. W jaki sposób teoria inteligentnego projektu (IP) zmieniła tę debatę? Jednej teorii naukowej - darwinizmowi została przeciwstawiona druga teoria naukowa - IP. W ten sposób debata wokół ewolucji została zdefiniowana $w$ ramach nauki. Obie teorie znajdują się na tym samym poziomie epistemicznym, co pomaga uniknąć pomieszania płaszczyzn. Religia nie jest już wykorzystywana przeciwko nauce ani nauka przeciwko religii. Oczywiście takie zdefiniowanie debaty wcale nie wyklucza poziomu filozoficznego czy teologicznego w dyskusji nad ewolucją. Daje jednak podstawy do owocnej debaty w ramach przyrodoznawstwa.

\subsection{Główne argumenty na rzecz inteligentnego projektu}

Podstawowe twierdzenie teorii inteligentnego projektu można sformułować w następujący sposób:

Przynajmniej niektóre struktury odkrywane i badane przez naukę noszą ślady bycia zaprojektowanymi, a nie powstania na mocy przypadku lub konieczności.

Z definicji tej nie wynika ani to, że wszystko, co widzimy w przyrodzie, na pewno jest zaprojektowane, ani to, że zaprojektowane struktury są doskonałe. Innymi słowy zwolennicy teorii inteligentnego projektu uznają, że wiele rzeczy w przyrodzie rzeczywiście jest wynikiem działania praw przyrodniczych i przypadkowych zdarzeń bez żadnego udziału czynnika inteligentnego. Uznają również, że w przyrodzie mogą istnieć projekty niedoskonałe lub w jakiś sposób zniszczone przez czynniki przypadkowe.

Przeciwnicy teorii IP wysuwają czasem argument w rodzaju: „Bóg by tak nie zrobił” lub „ktoś, kto zaprojektowałby to w ten sposób, musiałby być wy- 
jątkowo złym projektantem". Oba twierdzenia nie trafiają jednak w cel, jakim jest teoria inteligentnego projektu. W ramach tej teorii nie mówi się bowiem o Bogu, tylko co najwyżej o skutkach Jego działania. Trudno zresztą - przynajmniej w chrześcijańskim kontekście - uznać, że jakiś człowiek wie lepiej, co Bóg powinien był zrobicíc ${ }^{14}$. Również sam fakt, że projekt jest niedoskonały, nie unieważnia twierdzenia, że jest to projekt.

W latach 90. ubiegłego wieku biochemik Michael Behe postawił tezę, że na poziomie komórkowym znajdujemy struktury, które można określić jako nieredukowalnie złożone. System nieredukowalnie złożony to układ kilku (lub więcej) części, które współdziałają razem w celu spełniania określonej funkcji, przy czym usunięcie jednej części uniemożliwiłoby dalsze spełnianie podstawowej funkcji systemu. W tym kontekście warto odnotować, że wielu krytyków teorii inteligentnego projektu twierdzi, że jej zwolennicy uważają, że świat biologii jest zbyt skomplikowany, aby powstał przypadkowo. Zapewne twierdzenie to jest prawdziwe, ale nie ono stanowi istotę argumentu Behego. Nie chodzi o to, że dane struktury biologiczne są bardzo złożone, ale że są złożone w sposób nieredukowalny. Sztandarowy przykład Behego stanowi wić bakteryjna. Wypada teraz omówić nieco bliżej ten przykład nieredukowalnej złożoności.

Niektóre komórki wytwarzają organ umożliwiający im przemieszczanie się w płynach. Jest to tak zwana wić, która przyczepiona jest do zakrzywionego przegubu. Przegub z kolei poruszany jest ruchem obrotowym, co w sumie wywołuje efekt podobny do śruby napędowej statku wodnego. Zaskoczeniem dla biologów było odkrycie, że silnik wici ma bardzo podobną budowę i zasadę działania do silników budowanych przez ludzi. Ma stator i rotor, serię łożysk i wał napędowy. Wielokrotne eksperymenty potwierdziły, że jeżeli usuniemy choć jedno z pięćdziesięciu białek budujących wić, cały system przestanie spełniać swoją podstawową funkcję. Zatem te pięćdziesiąt białek to części wici, które muszą być obecne wszystkie naraz i odpowiednio ułożone, aby wić spełniała swoją podstawową funkcję, czyli poprzez ruch wirowy dawała siłę napędową bakterii.

14 Dobry przykład, jak błędna okazała się tego typu argumentacja, stanowi debata na temat unerwienia oka ludzkiego. Niektórzy krytycy twierdzili bowiem, że nerwy w oku są odwrócone tyłem do przodu. Nie dosyć, że taki układ wygląda dość dziwnie, to jeszcze sprawia wrażenie mało wydajnego (utrudniony dostęp światła do siatkówki oka). Zwolennicy teorii IP wykazali jednak, że ponieważ oko działa z niezwykłą precyzją i wydajnością, jego komórki wymagają więcej tlenu. I tylko taki układ nerwów, jaki faktycznie znajdujemy w oku, zapewnia dostateczny dopływ tlenu. Projekt, który najpierw uważano za niedoskonały, okazał się nie tylko optymalny, ale także bardzo wydajny. 
Nieredukowalna złożoność ma dwa aspekty - z jednej strony wyklucza darwinistyczną interpretację biologii, z drugiej zaś potwierdza konieczność inteligentnego czynnika do jej powstania. Dlaczego tak się dzieje? Spróbujmy pokrótce wyjaśnić oba aspekty nieredukowalnej złożoności.

Jak już mówiliśmy, zdaniem Darwina wszystko, co widzimy w biologii, jest owocem długotrwałych, stopniowych zmian jakichś bardzo prostych form organicznych ku formom coraz bardziej złożonym. Ewolucja postępuje małymi krokami, kiedy to drobne mutacje nadają organizmowi przewagę selekcyjną i zostają utrwalone w populacji za pomocą naturalnej selekcji. Koncepcja ewolucyjna zakłada, że był taki czas, kiedy żadna bakteria nie miała wici bakteryjnej, ale w końcu, na drodze długotrwałych modyfikacji jakiejś struktury organicznej, taka wić powstała i zaczęła spełniać swoją funkcję. Scenariusz ewolucyjny napotyka jednak poważny problem. Otóż naturalna selekcja zachowuje tylko to, co daje jakąś korzyść. A korzyść dają tylko nowe organy lub nowe funkcje. Innymi słowy, jeżeli dany narząd nie spełnia swojej funkcji, to nie będzie faworyzowany przez naturalną selekcję, ponieważ nie będzie dawał żadnej przewagi konkurencyjnej nad innymi organizmami. Ale żeby wić bakteryjna (czy jakikolwiek inny system nieredukowalnie złożony) mogła spełniać swoją funkcję, musi mieć wszystkie części. Przypadkowy skok od braku wici do sprawnej wici jest zbyt duży dla ewolucji. Zatem wić nie może powstać w jednym kroku ewolucyjnym. Nie może także powstać w wielu krokach, ponieważ tak długo, jak długo nie jest gotowa, nie spełnia funkcji i będzie obojętna dla naturalnej selekcji (najprawdopodobniej jednak niesprawna wić „w trakcie budowy" zostałaby po prostu wyeliminowana przez naturalną selekcję). Zatem wić bakteryjna nie może powstać na drodze ewolucji darwinowskiej.

$\mathrm{Z}$ drugiej strony istnienie wici świadczy o konieczności istnienia inteligentnego czynnika w powstaniu struktur biologicznych. Wić stanowi bowiem zespół licznych elementów dobranych pod kątem spełniania jednej funkcji. Spośród znanych nam czynników działających w przyrodzie tylko inteligentny czynnik - taki jak ludzki inżynier - potrafi wybierać pod kątem upatrzonego celu. Aby powstał system nieredukowalnie złożony, konieczny jest czynnik mogący przewidzieć ostateczny kształt danego systemu i dobrać odpowiednio części w taki sposób, aby spełniały oczekiwaną funkcję. Zatem wić bakteryjna nie może powstać na drodze przypadku i konieczności, musi zadziałać czynnik inteligentny. Biologowie, którzy uznają rolę takiego czynnika w kształtowaniu świata biologii, nie są zdziwieni faktem, że w XX wieku odkryliśmy na poziomie komórkowym szereg miniaturowych urządzeń, które ludzcy inżynierowie wytwarzali już wcześniej w dużej skali. Oprócz 
wici, która stanowi śrubę napędzaną silnikiem elektrycznym, odkryto także pompy ssąco-tłoczące, zaawansowany system transportu oraz program - kod genetyczny działający niemal identycznie jak program komputerowy. Wszystkie te urządzenia w skali mikro wskazują na konieczność udziału czynnika inteligentnego w powstaniu świata biologii.

\subsection{Czy inteligentny projekt jest teoria naukowa?}

Niektórzy przeciwnicy teorii inteligentnego projektu uważają jednak, że teoria ta nie może mieć miejsca w nauce, gdyż stanowi koncepcję religijną. Jako taka mogłaby być nauczana na lekcjach religii, ale nie na lekcjach biologii czy na świeckich uniwersytetach. Mimo to zwolennicy nieustannie utrzymują, że inteligentny projekt ma swoje miejsce w nauce.

Niewątpliwie spór o naukowy status inteligentnego projektu zależy przede wszystkim od tego, jak zdefiniujemy naukę. Obecnie, w dobie wszechobecnego naturalizmu i materializmu, naukę definiuje się czasem jako poszukiwanie naturalnych przyczyn zjawisk. Za przyczynę naturalną uznaje się jednak jedynie przyczyny materialne, takie jak własności materii, prawa przyrodnicze, zjawiska kwantowe lub międzygalaktyczne itp. W związku z tym teorię IP często nazywa się nienaukową, to znaczy należącą do sfery filozofii lub religii. Nieraz mówi się, że IP to ukryta lub jawna forma kreacjonizmu ${ }^{15}$. Zauważmy jednak, że kreacjonizm to bardzo specyficzna koncepcja religijna, która mówi o bardzo specyficznym rodzaju działania Bożego. Tymczasem IP nie mówi nic o Bogu, tym bardziej nie określa, w jaki sposób Bóg miałby działać w stworzeniu. IP zatrzymuje się na stwierdzeniu, że do wyjaśnienia pewnych elementów świata naturalnego jest potrzebny czynnik inteligentny. Zatem ta teoria per se nie wymaga nawet istnienia Boga osobowego, nie mówi o działaniu nadprzyrodzonym, nie odwołuje się do żadnej religii ani świętych tekstów. Wykrywanie projektu odbywa się za pomocą metody naukowej.

To, czy IP łamie naturalizm metodologiczny, zależy przede wszystkim od tego, jak zdefiniujemy naturę. Jeżeli przyjmujemy, że czynnik inteligentny jest zawsze ponadnaturalny, to jego wykrycie w ramach nauki oznaczałoby złamanie zasady metodologicznego naturalizmu, tyle że wielu twórców nowożytnej nauki, włączając Kopernika i Newtona, nie przyjmowało zasady naturalizmu jako naczelnej i nieuniknionej zasady w nauce. Wyraźnie mówili oni, że choć

$15 \quad$ Na przykład artykuł w anglojęzycznej Wikipedii już w pierwszych zdaniach informuje czytelników, że IP to pseudonauka i forma kreacjonizmu. Zob. http://en.wikipedia.org/ wiki/Intelligent_design [02.03.15]. 
świat działa dzięki prawom nadanym przez Stwórcę, te same prawa nie mogły tego świata ukształtować ${ }^{16}$.

Jak się wydaje, również dzisiaj wykrywanie śladów działania inteligencji stanowi ważną część wielu dyscyplin naukowych, włączając kryminalistykę, archeologię i informatykę. Zwolennicy IP twierdzą, że podobnie jak archeolog potrafi odróżnić, czy kawałki skały zostały wykonane przez inteligentnego twórcę narzędzi, czy może zwyczajnie odłupane przez przypadkowe siły przyrody (woda, powietrze), tak też biolog jest w stanie odróżnić, które elementy świata ożywionego (DNA, systemy nieredukowalnie złożone) powstały dzięki działaniu jakiejś inteligencji. Odrzucenie możliwości naukowego rozpoznania działania inteligentnego oznaczałoby unieważnienie sporej części współczesnej nauki. Na tej samej zasadzie teoria IP może być integralną częścią nauki takiej jak biologia.

\subsection{Czy inteligentny projekt jest argumentem typu „bóg zapchajdziura”?}

Jednym z popularnych zarzutów wysuwanych przez teologów względem teorii IP jest twierdzenie, że jest to argument w rodzaju „boga zapchajdziury" (ang. god of the gaps). Tego typu argumentacja polega na tym, że gdy nie znamy naturalnej przyczyny zjawiska, stwierdzamy natychmiastowo, że musi je sprawiać sam Bóg. Przeciwnicy argumentu „boga zapchajdziury” uważają, że Bóg znika z naszej wiedzy w momencie, gdy odkrywamy kolejne naturalne przyczyny zjawisk. Dochodzi wtedy do zjawiska wypychania Boga z luk naszej wiedzy i cała wiara w Boga może okazać się jedynie złudzeniem. Czy problem ten dotyczy teorii IP? Wydaje się, że nie. A są ku temu przynajmniej trzy powody.

16 Kopernik w swoim głównym dziele, które zrewolucjonizowało światową astronomię, wprost odwołał się do Boga: „Któż bowiem, zgłębiając te rzeczy [astronomię] i widząc, jak wszystko w nich ustanowione jest w najlepszym ładzie i boską kierowane wolą, nie wzniesie się na wyżyny cnoty [...] i nie będzie podziwiał Stwórcy wszechrzeczy, w którym się mieści całe szczęście i wszelkie dobro?”. O obrotach, przeł. M. Brożek, Warszawa-Kraków 1976, s. 7. Z kolei Newton wyraźnie rozróżniał pytanie „jak?” od pytania „skąd?”: „Chociaż ciała te mogą, w rzeczy samej, pozostawać w swoich orbitach poprzez same prawa ciążenia, jednak w żaden sposób nie mogły one początkowo przyjąć regularnych pozycji tychże orbit z tych praw [...]. [Tak więc] ten najpiękniejszy system Słońca, planet i komet może pochodzić jedynie z planu i mocy inteligentnej i potężnej Istoty". I. Newton, Mathematical Principles of natural philosophy and his system of the world (1686), trans. A. Motte, ed. F. Cajori, R. T. Crawford, Berkeley 1934, s. 543-44. 
Po pierwsze, aby określić, czy dana struktura jest pochodną działania inteligencji, trzeba najpierw dobrze poznać ową strukturę. Dopiero kiedy szczegółowo poznaliśmy zasadę działania wici bakteryjnej oraz określiliśmy jej elementy składowe i to, że wszystkie te elementy są potrzebne do jej funkcjonowania, mogliśmy wnioskować o inteligentnym projekcie. Zatem to właśnie znajomość zjawisk, a nie niewiedza leży u podstaw teorii IP.

Po drugie, o projekcie wnioskujemy na podstawie podobieństwa $\mathrm{z}$ działaniem inteligencji, którą znamy, czyli człowieka. Wiemy, że pewien rodzaj skutków w przyrodzie wywołują jedynie ludzie. Na przykład gdy widzimy urządzenia nieredukowalnie złożone, takie jak pułapka na myszy, różnego rodzaju silniki czy zegary, za każdym razem ich twórcami są ludzie. W oparciu o wiedzę doświadczalną na temat skutków działania ludzkiej inteligencji uzasadnione jest ekstrapolowanie tych doświadczeń i uznanie działania czynnika inteligentnego tam, gdzie przyroda ujawnia podobne jakościowo skutki. Zatem ponownie: u podstaw IP leży wiedza. W tym przypadku znajomość innego rodzaju inteligencji, która wywołuje podobne skutki.

Po trzecie nie wiadomo, jakim dokładnie kryterium poszukiwania przyczyn zjawisk naturalnych posługują się przeciwnicy IP. Wydaje się bowiem, że każde uznanie działania Boga w historii byłoby podatne na zarzut „boga zapchajdziury”. Zatem argument „boga zapchajdziury” można skutecznie ominąć tylko wtedy, gdy a priori przyjmie się, że żadne zjawisko w przyrodzie nie może mieć nadprzyrodzonego wyjaśnienia, lecz musi się sprowadzać do przyczyn materialnych. Nie wydaje się jednak, aby takie odgórne przyjęcie zasady naturalizmu było zgodne z chrześcijańską wizją świata. Zwolennicy IP postulują, aby szukać najlepszych wyjaśnień, a nie określać odgórnie, jakie wyjaśnienia są najlepsze. Ta druga postawa mogłaby bowiem prowadzić do redukcjonizmu, w którym nawet inteligentne czynniki działające $\mathrm{w}$ przyrodzie zostałyby zastąpione ślepymi siłami natury. Podsumowując, IP nie jest argumentem typu „bóg zapchajdziura”. Przeciwnie, aby móc wnioskować o projekcie, najpierw trzeba dobrze poznać dane zjawisko przyrodnicze. Zatem to wiedza, a nie „niewiedza” jest warunkiem rozpoznania IP.

\section{Jan Paweł II o ewolucji}

Trzeba zauważyć, że nie ma czegoś takiego jak „nauczanie Jana Pawła II o ewolucji”. Papież ten nigdy nie wydał dokumentu, takiego jak na przykład encyklika, w którym omówiłby zagadnienie ewolucji w kontekście 
katolickim. Nieliczne wypowiedzi lub raczej okazjonalne wzmianki zawarte w papieskim przemówieniu i kilku katechezach można by zmieścić na jednej stronie maszynopisu. Można więc uznać, że Jan Paweł II nie rozstrzygnął sporu o ewolucję, zostawiając ten problem dalszym pokoleniom teologów i kolejnym papieżom.

Spośród kilku papieskich wypowiedzi warto przywołać dwie z lat 19851986 oraz przemówienie do Papieskiej Akademii Nauk z 1996 roku. Pierwsze nawiązanie do teorii ewolucji występuje w katechezie z 10 lipca 1985 roku, gdy papież omawiał zagadnienie rozumowych argumentów za istnieniem Boga. Odwoływał się tutaj do długiej tradycji chrześcijańskiej, która podążając za słowami św. Pawła (Rz 1,20), wskazywała na możliwość poznania niewidzialnego Boga $\mathrm{z}$ dzieł poznawanych zmysłami i rozumem $\mathrm{w}$ świecie widzialnym. Papież mówił: „Wszystkie spostrzeżenia dotyczące rozwoju życia prowadzą do analogicznego wniosku. Ewolucja istot żyjących, która stanowi przedmiot badań naukowych zmierzających do określenia jej etapów i wyróżnienia działających w niej mechanizmów, ukazuje zadziwiającą wewnętrzną celowość. Owa celowość, prowadząca wszystkie byty w tym samym kierunku, nad którą nie posiadają one władzy ani nie są za nią odpowiedzialne, każe domyślać się Ducha, który jest ich wynalazcą i stwórcą"17. I dalej w tej samej katechezie: „Niektórzy przeciwstawiają tym wskazówkom prowadzącym do istnienia Boga Stwórcy dzieło przypadku lub wewnętrznych mechanizmów materii. Mówić o przypadku w odniesieniu do świata, który ukazuje tak bardzo złożoną organizację elementów i tak zadziwiającą celowość życia, oznacza rezygnację z próby wytłumaczenia świata, który jawi się naszym oczom. $\mathrm{W}$ rezultacie jest to jednoznaczne $\mathrm{z}$ chęcią uznania skutków bez przyczyny. Jest to abdykacja ludzkiego rozumu, który w ten sposób zaniechał myślenia, odrzucił próby rozwiązania swoich problemów"18.

Drugie nawiązanie, które należy tutaj przywołać, miało miejsce 29 stycznia 1986 roku. Papież mówił wtedy: „Sam opis dzieła stworzenia zasługuje na to, aby był często odczytywany i rozważany, w liturgii i poza liturgią. [...] Tekst ten ma znaczenie nade wszystko religijne i teologiczne. Nie sposób szukać w nim jakichś elementów istotnych z punktu widzenia szczegółowych nauk przyrodniczych. Tak więc wielokierunkowe badania dotyczące powstania i rozwoju poszczególnych gatunków w przyrodzie nie znajdują w tym opisie

17 Katecheza z 10 lipca 1985 roku. Dowody na istnienie Boga, [w:] Katechezy Ojca Świętego Jana Pawła II. Bóg Ojciec, Kraków-Ząbki 1999, s. 69.

18 Tamże, s. 70. 
ani żadnej wiążącej dyrektywy, ani też istotnego ograniczenia. Co więcej, z prawdą o stworzeniu świata widzialnego - tak jak jest ona przedstawiona w Księdze Rodzaju - nie koliduje również w zasadzie teoria ewolucji przyrody, jeśli nie wyklucza się w niej przyczynowości Bożej" ${ }^{\prime 9}$.

Te dwie papieskie wypowiedzi, choć nie są jedynymi nawiązaniami do ewolucji, dobrze oddają stosunek Jana Pawła II do tej teorii. Trzeba jednak zauważyć, że papież nie zdefiniował dokładnie, w jakim znaczeniu mówi o ewolucji. Pierwszy cytowany fragment sugeruje, że chodzi o makroewolucję biologiczną, gdyż jest tam mowa o zmierzaniu wszystkich bytów w tym samym kierunku. Jednak ściśle rzecz biorąc, idea ogólnego postępu przyrody wyrażona w tej wypowiedzi nie jest sprzeczna z koncepcją ewolucji ograniczonej jedynie do zmian w obrębie gatunków. Ponadto idea makroewolucji biologicznej we współczesnej nauce jest sformułowana w ramach teorii neodarwinistycznej. Ta z kolei wyklucza jakikolwiek postęp czy zmierzanie przyrody w określonym kierunku. Zdaniem darwinistów przyroda - zarówno jej poszczególne elementy, jak i jej całość - nie ma określonego celu, jest ślepa tak samo jak ślepy jest mechanizm przypadkowych mutacji i naturalnej selekcji znajdujący się u podstaw ewolucji. Należy więc uznać, że Jan Paweł II odrzucił centralne twierdzenie darwinizmu, choć nie odrzucił idei naturalnego pochodzenia wszystkich bytów od jednego przodka. Taka interpretacja zostaje jeszcze wzmocniona, gdy weźmiemy pod uwagę drugi z cytowanych fragmentów, w którym papież uznaje niemożność rozpoznania celowości w przyrodzie za znak "abdykacji ludzkiego rozumu”. Ponadto stwierdza, że niektórzy przeciwstawiają wskazówkom płynącym z przyrody na temat możliwości poznania Boga dzieło przypadku lub wewnętrzne mechanizmy materii. Nie sposób uniknąć wrażenia, że chodzi tu właśnie o darwinizm, w którym celowość i Boże działanie zastępuje się przypadkiem i naturalną selekcją.

Trzeci cytowany fragment potwierdza, że Jan Paweł II nie widział zasadniczej sprzeczności między ideą ewolucji a biblijnym opisem stworzenia. Ponownie nie wiemy dokładnie, co oznacza określenie „teoria ewolucji przyrody". Jeżeli ewolucja jest rozumiana tutaj jako po prostu zmiana w czasie, to z pewnością nie stanowi ona punktu kontrowersyjnego ani dla nauki, ani dla religii. Jeżeli jednak ewolucja to ta wielka materialistyczna opowieść,

19 Katechezy Ojca Świętego Jana Pawła II, dz. cyt., s. 135-136. Cytowane fragmenty nie są jedynymi wypowiedziami Jana Pawła II z tego okresu. Więcej odnośników można znaleźć w mojej książce Kościót a ewolucja (Warszawa 2012). 
w której uznaje się, że wszystko, co widzimy w przyrodzie, powstało na zasadzie materialnych procesów, to biblijny opis stworzenia z pewnością stoi w sprzeczności z taką wizją. Biorąc pod uwagę kontekst wypowiedzi, jak też najbardziej naturalne rozumienie słów, można uznać, że papież akceptuje makroewolucję w jakiś sposób kierowaną lub zaprogramowaną przez Boga.

Przemówienie z 1996 roku do Papieskiej Akademii Nauk w zasadzie nie wnosi istotnych modyfikacji do stanowiska wyrażonego przez Jana Pawła II w połowie lat 80 . Warto jednak przyjrzeć się temu przesłaniu bliżej, ponieważ stało się ono przedmiotem licznych nadinterpretacji ze strony teistycznych ewolucjonistów $^{20}$. Zdanie, które wywołało największy oddźwięk, brzmiało: „Dzisiaj, prawie pół wieku po publikacji encykliki, nowe zdobycze nauki prowadzą do rozpoznania w teorii ewolucji czegoś więcej niż hipotezy"21. Z kontekstu wypowiedzi wynika, że „coś więcej niż hipoteza” to teoria. Jan Paweł II zwrócił więc uwagę na wzrost rangi ewolucji przez to, że uznał, że stanowi ona coś więcej niż hipotezę. Jednak nazwanie ewolucji teorią nie wnosi żadnej nowości do papieskiej myśli, gdyż już w katechezach środowych z 1985 roku Jan Paweł II używał określenia „teoria” w odniesieniu do ewolucji. Określenie „teoria ewolucji” pojawia się nawet w małej książeczce, którą napisał w roku 1950, z tym że tam jest użyte w celu podkreślenia, że ewolucja jest ,jedynie teorią" a nie „udowodnioną prawdą naukową"22. Wydaje się zatem, że to nie kwestia statusu ewolucji jako teorii czy hipotezy jest

\footnotetext{
20 O przykładach takich nadinterpretacji zob. Kościół a ewolucja, dz. cyt., s. 286-293.

21 Przesłanie do członków Papieskiej Akademii Nauk z 22 października 1996 roku w związku z sesją Powstanie i ewolucja życia, „Acta Apostolicae Sedis” [dalej: AAS] 89 (1997), s. 186-190. Polski tekst dostępny w: „L'Osservatore Romano” 1 (1997), s. 18-19. Także w internecie, na przykład tutaj: http://www.jezuici.krakow.pl/nw/doc/jp2ewolucja.htm [02.03.15].

22 „Otóż - jak wiemy (do szczegółowych danych tej teorii tutaj się nie uciekamy), teoria ewolucji wywodzi człowieka od pewnych form zwierzęcych, od tych mianowicie, których organizm swą budową najbardziej zbliża się do ludzkiego. Jako dowody swej prawdziwości wskazują na rzekome formy pośrednie, poprzez które rozwój się dokonywał. Od tej strony brana teoria ewolucji musi uchodzić za naukową hipotezę przyrodniczą, hipotezę, która ciągle jeszcze szuka coraz pełniejszego dla siebie uzasadnienia i ostatecznego sprecyzowania swoich wniosków (np. sprawa „linii genealogicznej”). Ponieważ zaś jest hipotezą, na razie nie możemy tej teorii przyjmować jako niezbitego pewnika i na tej podstawie snuć jakichś wniosków odnośnie do samej istoty człowieka. [...] Encyklika Piusa XII Humani Generis przypisuje teorii ewolucji należne jej znaczenie przyrodniczej hipotezy i licząc się z dalszymi wynikami badań w tej dziedzinie, zawsze jednak - idąc zarówno za przesłankami Objawienia, jak też za wnioskami, do których doprowadza nas rozumowa analiza ludzkiej istoty, zacieśnia zakres teorii ewolucji wyłącznie do ludzkiego ciała. Duchowa bowiem dusza ludzka mogła
} 
najważniejsza w papieskim przesłaniu. Na pierwszy plan wysuwa się pytanie, czym jest owo „więcej”, którego Jan Paweł II zdaje się nie definiować jednoznacznie. Można zauważyć, że ewolucja we współczesnej nauce i kulturze jest nie tylko teorią, ale wręcz paradygmatem, światopoglądem, „filozofią pierwszą", w ramach której rozpatruje się wszystkie fenomeny świata natury i kultury. I w tym sensie można powiedzieć, że ewolucja jest czymś znacznie więcej niż hipotezą, ale także należy dodać, że przekroczyła swoje kompetencje jako pojęcie naukowe.

W dalszym ciągu przemówienia Jan Paweł II zwrócił uwagę na wymagania, przed jakimi stoi każda teoria naukowa: „Teoria jest konstrukcją metanaukową, odrębną od rezultatów obserwacji, ale zgodną z nimi. [...] Teoria okazuje się słuszna w takiej mierze, w jakiej pozwala się zweryfikować; jest nieustannie oceniana w świetle faktów; kiedy przestaje uwzględniać fakty, ujawnia swoje ograniczenia i nieprzydatność. Wymaga wówczas ponownego przemyślenia. Ponadto sformułowanie teorii takiej jak ewolucjonizm wymaga nie tylko przestrzegania zgodności z danymi uzyskanymi $\mathrm{z}$ obserwacji, ale także zapożyczenia pewnych pojęć z filozofii przyrody. W rzeczywistości należy mówić nie tyle o teorii, ile raczej o teoriach ewolucji. Ich wielość wynika $\mathrm{z}$ jednej strony $\mathrm{z}$ różnych sposobów wyjaśniania mechanizmu ewolucji, a $\mathrm{z}$ drugiej $-\mathrm{z}$ różnych filozofii, które stanowią ich punkt odniesienia" ${ }^{23}$. Zatem zdaniem Jana Pawła II w istocie istnieje wiele różnych teorii ewolucji, które mają także swoje filozoficzne podstawy. Ponieważ w poprzednich wypowiedziach papież odrzucił te teorie, które sprowadzają wszystko do przypadku i konieczności, można uznać, że również tutaj w istocie zwraca się on przeciwko darwinistycznej teorii ewolucji. Ponadto, zdaniem autora, teoria jest oceniana $\mathrm{w}$ świetle faktów. Wielu współczesnych biologów, i to nie tylko będących zwolennikami teorii inteligentnego projektu, dostrzega ogromne rozbieżności między obserwowanymi faktami a przewidywaniami teorii neodarwinistycznej ${ }^{24}$. Niektóre fakty zaprzeczają nawet samej idei makroewolucji biologicznej. Jeżeli taki jest stan nauki, to według papieskich słów teoria neodarwinistyczna wymaga ponownego przemyślenia.

zostać bezpośrednio stworzona tylko przez Boga." K. Wojtyła, Rozważania o istocie człowieka, Kraków 1999, s. 93.

23 Przesłanie do członków Papieskiej Akademii Nauk z 22 października 1996 roku, AAS 89 (1997), s. 188.

24 Zob. np. książkę filozofa ateisty: Mind and Cosmos: why the materialist neo-Darwinian conception of nature is almost certainly false, Oxford-New York 2012. 


\section{Kościół a ewolucja - obecny stan nauczania}

Z przytoczonych wypowiedzi Jana Pawła II nie wyłania się całkiem jednoznaczny stosunek świętego papieża do idei makroewolucji biologicznej lub teorii Darwina. Niestety, uwzględniając także wypowiedzi poprzedników i następców Jana Pawła II, jak również wysokich hierarchów Kościoła, nie znajdujemy w nich jednoznacznej oceny teorii Darwina. Oczywiście Kościół odrzuca materialistyczną interpretację przyrody, ale jednocześnie przyjmuje możliwość makroewolucji biologicznej. Jednak jedyny znany mechanizm takiej ewolucji jest właśnie czysto materialistyczny. W jaki sposób więc można spójnie twierdzić, że ewolucja jest zgodna z przesłaniem biblijnym, i odrzucać przypadek jako główny motor powstania całej różnorodności stworzeń? Najwyraźniej obecnie w Kościele akceptowane są różne - nawet wzajemnie wykluczające się - poglądy na pochodzenie gatunków. Spróbujmy teraz dokonać pewnego podsumowania, tak abyśmy mogli zorientować się, gdzie jako katolicy jesteśmy, jakie poglądy są obecne w debacie i jak wyglądają wzajemne zależności między nimi.

Wszystkie teorie na temat pochodzenia gatunków (gatunków naturalnych istot żywych) można sklasyfikować do jednej z czterech kategorii: materialistyczny ewolucjonizm, teistyczny ewolucjonizm, progresywny kreacjonizm i kreacjonizm młodej Ziemi. Jest jasne, że materialistyczny ewolucjonizm (czy to w formie ateistycznej, czy monistycznej) nie jest poglądem akceptowalnym w ramach ortodoksji chrześcijańskiej. W Kościele akceptowane są trzy pozostałe poglądy.

Teistyczny ewolucjonizm to idea, że Bóg ukształtował całą różnorodność stworzeń, posługując się wyłącznie przyczynami wtórnymi, takimi jak procesy ewolucyjne, mutacje, przypadkowa zmienność, dryf genetyczny, naturalna selekcja itp. W teistycznym ewolucjonizmie nie wyklucza się ani tak czy inaczej rozumianej opatrzności Bożej, ani Boga jako źródła wszelkiego bytu, natomiast wyklucza się ideę specjalnego stworzenia, to znaczy działania Boga w sposób nadprzyrodzony i bezpośredni w historii kształtowania świata. W teistycznym ewolucjonizmie zazwyczaj rozróżnia się poziom naukowy, na którym za powstanie gatunków miałyby odpowiadać procesy neodarwinistyczne, oraz poziom teologiczny, na którym można mówić o działaniu Boga (np. idea nieustannego stwarzania lub ewolucji uprzednio zaprogramowanej, ang. front-loading). Poziom nauk przyrodniczych jest zasadniczo niezależny od poziomu objawienia i dlatego śladów działania Bożego nie można rozpoznać, studiując fakty przyrodnicze. 
Progresywny kreacjonizm to pogląd, według którego Bóg działał w historii kształtowania świata w sposób bezpośredni i nadprzyrodzony. Nie oznacza to wszakże, że wszystko w historii naturalnej zostało ukształtowane w ten sposób. Bóg działał tam, gdzie natura nie miała mocy, aby wytworzyć zasadniczą nowość. Badania przyrodnicze mogą bardziej precyzyjnie ukazać ograniczenia natury i w ten sposób wskazać, gdzie zachodziła konieczność stwórczego działania Boga. W najbardziej klasycznej formie kreacjonizmu progresywnego uznaje się niezależne stworzenie gatunków (rozumianych jako gatunki naturalne). W tym ujęciu Pismo Święte i historia naturalna są jak dwie uzupełniające się księgi. Jedynie uważne czytanie obu ksiąg - zarówno nadprzyrodzonego objawienia, jak i faktów przyrodniczych - może odsłonić całą prawdę na temat pochodzenia różnorodności życia.

Kreacjonizm młodej Ziemi to pogląd, według którego świat został stworzony i ukształtowany mocą Boga, który podobnie jak w kreacjonizmie progresywnym działał w sposób bezpośredni i nadprzyrodzony w historii naturalnej; tyle że historia ta trwała bardzo krótko, gdyż tylko sześć dni rozumianych jako naturalny dzień obserwowany z Ziemi. Cała historia świata zamyka się w około sześciu tysiącach lat. Dane te wynikają z przesłania biblijnego. W tzw. kreacjonizmie naukowym te same wnioski dotyczące krótkiego czasu istnienia świata usiłuje się popierać danymi naukowymi. Jednak podobnie jak w teistycznym ewolucjonizmie kreacjonizm młodej Ziemi uznaje zasadniczą odrębność porządku objawienia i nauk przyrodniczych. Wiedzę na temat świata czerpie się z literalnej lektury Pisma Świętego.

Teoria inteligentnego projektu nie mówi, w jaki sposób projekt został wprowadzony do świata przyrody. IP jest bowiem teorią naukową, w ramach której twierdzi się jedynie, że niektóre struktury biologiczne zostały zaprojektowane, a nie powstały na zasadzie gry przypadku i konieczności. Dlatego IP może być zgodny z wieloma różnymi koncepcjami teologicznymi (podobnie jak Pismo Święte może być zgodne $z$ wieloma różnymi teoriami przyrodniczy$\mathrm{mi})$. IP jest zgodny z teistycznym ewolucjonizmem, ponieważ można uznać, że Bóg umieścił projekt $\mathrm{w}$ świecie w momencie jego pierwszego stworzenia lub nawet dodawał projekt i informację w trakcie samokształtowania się świata $\mathrm{w}$ procesie ewolucyjnym. IP jest zgodny z progresywnym kreacjonizmem, ponieważ nic nie stoi na przeszkodzie, aby Bóg umieścił informację i projekt w każdym nowym gatunku osobno w momencie jego stworzenia. IP jest również zgodny z kreacjonizmem młodej Ziemi, ponieważ całe stworzenie, które było sposobem umieszczenia projektu w przyrodzie ożywionej, mogło dokonać się na przestrzeni sześciu naturalnych dni, około 6 tysięcy lat temu. 
Poniższa tabela ukazuje trzy modele powiązania nauki i wiary w kontekście pochodzenia gatunków akceptowane obecnie w Kościele.

\begin{tabular}{|l|l|l|}
\hline \multicolumn{1}{|c|}{ A } & \multicolumn{1}{c|}{ B } & \multicolumn{1}{c|}{ C } \\
\hline Objawienie & Objawienie & Objawienie \\
\hline Teistyczny ewolucjonizm & Progresywny kreacjonizm & Teistyczny ewolucjonizm \\
\hline Inteligentny projekt & Inteligentny projekt & Teoria (neo)darwinistyczna \\
\hline Nauka & Nauka & Nauka \\
\hline
\end{tabular}

Cztery rzędy w tabeli reprezentują cztery poziomy ludzkiej wiedzy. Najwyżej znajduje się objawienie, czyli ponadnaturalna wiedza (w tym przypadku dotycząca świata) dana człowiekowi przez Boga. Na najniższym poziomie znajduje się nauka, czyli ta wiedza, którą człowiek nabywa sam poprzez badanie przyrody. W modelu A przyjmuje się, że najlepszą interpretację objawienia biblijnego stanowi teistyczny ewolucjonizm, czyli przekonanie, że Bóg nie stworzył gatunków osobno, tylko posłużył się procesami ewolucji. Przyjmuje się także, że wiedza przyrodnicza ujawnia istnienie projektu, zatem inteligentny projekt stanowi najlepszą interpretację biologii (w przeciwieństwie do darwinizmu). W modelu B przyjmuje się, że najlepszą interpretację zjawisk biologicznych stanowi teoria IP, ale w przeciwieństwie do modelu A uznaje się, że najlepszą interpretację Księgi Rodzaju stanowi niezależne stworzenie różnych gatunków na przestrzeni jakiegoś czasu, który pomagają określić badania naukowe (obecnie czas istnienia życia na Ziemi określa się na ok. 3,5 mld lat). Z kolei w modelu C przyjmuje się, że najbardziej popularna wersja teorii ewolucji, czyli neodarwinizm, stanowi najlepszą interpretację faktów biologicznych. Ponieważ darwinizm zakłada wspólne pochodzenie od jednego przodka, nie może być zgodny z progresywnym kreacjonizmem. I dlatego w modelu $\mathrm{C}$ przyjmuje się, że najlepszą interpretację przesłania biblijnego stanowi teistyczny ewolucjonizm.

Obecnie wszystkie trzy modele mają swoich reprezentantów w Kościele, zarówno wśród duchowieństwa, jak i świeckich, zarówno wśród naukowców, jak i teologów. Jak się wydaje, nauczanie Jana Pawła II, jak również Benedykta XVI najlepiej opisuje model A. Również wypowiedzi kard. Christopha Schönborna i biochemika Michaela Behego wskazują na ich poparcie dla modelu A. Z kolei teologowie i przyrodnicy, tacy jak Robert Stackpole, Paul Brown, Ann Gauger, autor tego artykułu oraz osoby związane z ruchem Reasons to Believe (Hugh Ross, Fazale Rana i in.) uznają, że model B najlepiej 
spełnia wymagania stawiane zarówno przez współczesną naukę, jak i poważną lekturę Księgi Rodzaju. Model C reprezentują przyrodnicy i teologowie tacy jak śp. arcybiskup Życiński, Kenneth Miller, Michał Heller, Francisco Ayala, George Coyne SI i osoby związane z fundacją BioLogos.

Wymienione osoby to zarówno protestanci, jak i katolicy. Fakt, że w samym Kościele katolickim istnieje taka różnorodność stanowisk, dowodzi, że kwestia ewolucji jest daleka od rozstrzygnięcia. Co ciekawe, różnice między poszczególnymi badaczami przekraczają tradycyjne podziały chrześcijan na konserwatystów i progresistów oraz katolików i protestantów. Czy można więc zaryzykować tezę, iż odnowa katolickiej nauki o stworzeniu ma głęboki wymiar ekumeniczny? Czy może prowadzić do przełamania wewnętrznych podziałów w Kościele? Jeżeli kwestia ewolucji miałaby rzeczywiście aż tak głębokie znaczenie dla przyszłości Kościoła, to niewątpliwie wraz z Janem Pawłem II powinniśmy uznać ją za coś więcej niż hipotezę. 